\title{
Pengembangan Asesmen Autentik Pembelajaran Tematik di Sekolah Dasar
}

\author{
Ima Wahyu Putri Utami, Muhardjito, Dedi Kuswandi \\ Universitas Negeri Malang
}

\begin{tabular}{l} 
INFO ARTIKEL \\
\hline Riwayat Artikel: \\
Diterima: 09-03-2020 \\
Disetujui: 07-05-2020 \\
\hline
\end{tabular}

\section{Kata kunci:}

Asesmen Autentik Pembelajaran Tematik

\author{
Alamat Korespondensi: \\ Ima Wahyu Putri Utami \\ Jurusan/Prodi Penulis 1 \\ Universitas Negeri Malang
}

\begin{abstract}
ABSTRAK
Abstract: Thematic learning which includes affective, cognitive, and pilomotor in the learning process has been implemented in elementary schools. Learning is at the core of an implementation of the curriculum, so that the assessment should be carried out continuously during the learning process. The aim of research and development to address the problems outlined above, namely: produce books of authentic assessment on thematic learning for elementary school teacher who has a class I level of validity, implementation, and high legibility. This research uses research and development model O'Malley and Pierce. Instrument data collecting the used is guidance of interview, documentation, sheet of validation, and questionnaire of response teacher. Interview and documentation used to know requirement exist in related/relevant field of authentic assessment. Sheet of validation used to know valid level of book product of assessment authentic. questionnaire of response teacher used to know level of implementation, and legibility of book product of assessment authentic. Mean result of evaluation expert validation, linguist, and tired character reached $86 \%$ with very valid criterion. Mean result of implementation of product of class teacher I A, I B, and tired I C 95\% with very valid criterion. Mean result of legibility of class teacher I A, IB, and tired IC 86\% with criterion very valid.
\end{abstract}

Abstrak: Pembelajaran tematik yang memasukkan sikap, pengetahuan, dan keterampilan dalam proses pembelajaran telah diterapkan di sekolah dasar. Pembelajaran merupakan inti dari suatu implementasi kurikulum, sehingga asesmen harus dilakukan secara terus-menerus selama proses pembelajaran. Tujuan penelitian \& pengembangan ini untuk menghasilkan buku asesmen autentik pada pembelajaran tematik bagi guru kelas I SD yang mempunyai tingkat kevalidan, keterterapan, dan keterbacaan yang tinggi. Metode penelitian \& pengembangan yang digunakan adalah model O'Malley \& Pierce. Instrumen pengumpulan data yang digunakan adalah pedoman wawancara, dokumentasi, lembar validasi, dan angket respon guru. Wawancara dan dokumentasi digunakan untuk mengetahui kebutuhan yang ada di lapangan terkait asesmen autentik. Lembar validasi digunakan untuk mengetahui tingkat kevalidan produk buku asesmen autentik. Angket respon guru digunakan untuk mengetahui tingkat keterterapan, dan keterbacaan produk buku asesmen autentik. Rata-rata hasil validasi ahli evaluasi, ahli bahasa, dan ahli karakter mencapai $86 \%$ dengan kriteria sangat valid. Rata-rata hasil keterterapan produk dari guru kelas IA, IB, dan IC mencapai 95\% dengan kriteria sangat valid. Rata-rata hasil keterbacaan dari guru kelas IA, IB, dan IC mencapai $86 \%$ dengan kriteria sangat valid. 
Jl. Semarang 5 Malang 65145 Jawa Timur Indonesia

E-mail: imawahyu_90@ymail.com

\section{PENDAHULUAN}

Seiring dengan perkembangan dan tantangan zaman, pendidikan harus berkembang agar bangsa ini tidak tertinggal dengan bangsa lain. Jika dari tahun ke tahun pendidikan di negara dilakukan dengan cara dan isi yang sama, maka hasil dari pendidikan tersebut akan tidak berguna untuk menyelesaikan permasalahan yang lebih baru. Langkah pengembangan pendidikan salah satunya dengan melakukan perubahan maupun pengembangan kurikulum yaitu perkembangan kurikulum 2006 menjadi kurikulum 2013. Perkembangan kurikulum tersebut berdampak pada pembelajaran di Sekolah Dasar yang diubah dari mata pelajaran yang terpisah-pisah menjadi pembelajaran tematik (Ain \& Kurniawati, 2013).

(Akbar, 2013) menyatakan pembelajaran tematik adalah sistem pembelajaran mengkondisikan siswa baik secara kelompok maupun individu untuk mencari, menggali, dan menemukan konsep keilmuan secara holistik, bermakna, dan autentik melalui tema tertentu. (Trianto, 2012) mengemukakan pengertian pembelajaran tematik/terpadu adalah sebuah model pembelajaran yang memadukan beberapa materi pembelajaran dari berbagai kompetensi dasar dari satu ataupun beberapa mata pelajaran. Definisi lain mengenai pembelajaran tematik menurut (Fogarty, 1991) adalah model pembelajaran yang mencampurkan antara beberapa disiplin ilmu yang telah memprioritaskan pembelajaran dari tiap-tiap disiplin ilmu dan memasukkan keterampilan, konsep dan sikap pada proses pembelajaran tersebut. Jadi pembelajaran tematik adalah suatu pembelajaran yang mengkondisikan siswa baik secara individu maupun kelompok untuk mencari, menggali, dan menemukan konsep ilmu dari tema yang berisi materi dari beberapa mata pelajaran serta memasukkan keterampilan, dan sikap dalam proses pembelajaran.

Mengingat suatu pembelajaran merupakan inti dari suatu implementasi kurikulum, maka idealnya asesmen harus dilakukan secara terus menerus selama proses pembelajaran. Asesmen yang dilakukan secara terus menerus dalam proses pembelajaran tersebut pada dasarnya merupakan asesmen autentik (Astuti et al., 2018).

Menurut (Arifin, 2013) asesmen autentik yaitu asesmen yang digunakan untuk mengetahui tingkat kemampuan siswa secara nyata tanpa dibuat-buat baik di dalam kelas maupun dalam kegiatan sehari-hari yang dilakukan oleh siswa. (Mueller, 2014) menyatakan bahwa asesmen autentik merupakan suatu bentuk tugas dunia nyata yang bermakna, sesuai dengan pengetahuan dan keterampilan yang diajarkan kepada siswa. Jadi, asesmen autentik adalah suatu tugas dunia nyata yang bermakna baik di lingkungan kelas maupun kegiatan sehari-hari siswa yang sesuai dengan pengetahuan dan keterampilan siswa.

Meskipun asesmen autentik baru-baru ini telah dikrekomendasikan untuk digunakan, namun masih ada kesenjangan antara harapan diterapkannnya asesmen autentik dan kondisi lapangan. Adapun kesenjangan tersebut antara lain guru belum benar-benar paham apa itu asesmen autentik (Marhaeni, 2015). Guru telah menerapkan portofolio, namun tidak ada tindak lanjut pemberian skor. Guru tidak menilai performa siswa. Guru kesulitan mendeskripsikan nilai siswa. Asesmen yang biasah dilakukan hanya aspek pengetahuan, sementara asesmen harus dilakukan pada tiga aspek, yaitu sikap, pengetahuan, dan keterampilan. Guru tidak menyiapkan instrumen terlebih dahulu ketika akan melakukan asesmen. Belum ada buku asesmen autentik yang khusus kelas I SD, sehingga guru berharap ada buku asesmen autentik yang mempunyai petunjuk yang jelas .

Selain itu hasil analisis terhadap buku guru (Kemendikbud, 2013) menunjukkan bahwa pada buku guru telah disajikan panduan asesmen, namun belum cukup jelas dan lengkap. Analisis terhadap panduan asesmen pada buku guru didapat asesmen yang dikembangkan yaitu tes tertulis, unjuk kerja, observasi, dan portofolio. Panduan ataupun instrumen asesmen penugasan dan produk tidak disajikan pada buku guru. Pada instrumen asesmen unjuk kerja hanya disajikan contoh rubrik bernyanyi dan kegiatan diskusi saja, sementara unjuk kerja dalam membaca belum terlihat. Rubrik asesmen bernyanyi pun belum cukup rinci. Pengolahan nilai pada asesmen unjuk kerja hanya sebatas pengolahan nilai yang didapat siswa dari masingmasing tugas. Pengolahan nilai maupun penyimpulan nilai yang didapat siswa dari beberapa tugas belum disajikan. Instrumen observasi karakter/sikap pada buku guru hanya disajikan lembar pengamatan untuk menilai sikap siswa. Pada buku guru tidak disajikan rubrik, cara pengolahan nilai, dan penyimpulan nilai. Meskipun buku guru menyebutkan bahwa portofolio merupakan salah satu asesmen yang dikembangkan, 
namun panduan asesmen portofolio tidak disajikan pada buku guru. Jadi berdasarkan paparan mengenai analisis terhadap buku guru, maka dapat diketahui masih ada kekurangan pada buku guru.

Mengkaji kesenjangan antara kondisi lapangan dan tuntutan direkomendasikannya asesmen autentik, maka masalah tersebut perlu diselesaikan dengan mengembangkan buku asesmen autentik. Sehingga tujuan penelitian \& pengembangan ini yaitu menghasilkan buku asesmen autentik pada pembelajaran tematik untuk guru kelas I SD yang mempunyai tingkat kevalidan, keterterapan, dan keterbacaan yang tinggi (Kasmadi et al., 2016).

\section{METODE}

Metode penelitian \& pengembangan yang digunakan yaitu model pengembangan asesmen (Kovacek \& Bode, 1996). Adapun tahap-tahap model pengembangan asesmen (Kovacek \& Bode, 1996) yaitu. (1) build a team (membangun suatu tim), (2) determine the purpose (menentukan tujuan), (3) specify objective (menetapkan sasaran hasil), (4) conduct staff development (melakukan pengembangan staf), (5) collect example of authentic (mengumpulkan contoh asesmen), (6) adapt existing assessments or develop new ones (menyesuaikan asesmen yang ada atau mengembangkan yang baru), (7) try out the assessments (Uji coba asesmen), dan (8) review the assessments (meninjau ulang asesmen).

Untuk mengetahui kebutuhan di lapangan terkait asesmen autentik dilakukan observasi awal sebelum dilakukan pengembangan terhadapat produk buku asesmen autentik. Observasi awal dilakukan dengan melakukan observasi terhadap proses pembelajaran guru kelas I SDN Balongjeruk dengan bantuan video. Selain itu, dilakukan wawancara kepada dua guru kelas I SDN Balongkeruk. Data hasil observasi ketika proses pembelajaran dan hasil wawancara tersebut dianalisis dengan teknik deskriptif kualitatif. Hasil analisis data tersebut digunakan sebagai bahan untuk mengembangkan produk buku asesmen autentik yang sesuai dengan kebutuhan yang ada di lapangan.

Data yang diperoleh dari skor penilaian dari validator dan guru dianalisis dengan teknik deskriptif kuantitatif. Skor penilaian dihitung rumus persentase dari validator dan pengguna diadaptasi dari (Akbar, 2013) adalah, skor tingkat kevalidan dari ahli evaluasi, ahli bahasa, dan ahli karakter/sikap kemudian diratarata. Begitupun dengan skor penilaian keterterapan dan keterbacaan dari ketiga guru dirata-rata. Hasil ratarata dari validator maupun pengguna kemudian dianalisis dengan kriteria validitas, keterterapan, dan keterbacaan. Adapun kriteria validitas, keterterapan, dan keterbacaan tersebut dapat dilihat pada Tabel 1.

Tabel 1. Kriteria Tingkat Kevalidan, Keteterapan, dan Keterbacaan

\begin{tabular}{ccc}
\hline No. & Kriteria Validitas & Tingkat Kevalidan, Keterterapan, dan Keterbacaan \\
\hline 1. & $85,01 \%-100 \%$ & Sangat valid, atau dapat digunakan tanpa revisi. \\
2. & $70,01 \%-85,00 \%$ & Cukup valid, atau dapat digunakan namun perlu direvisi kecil. \\
3. & $50.01 \%-70,00 \%$ & Kurang valid, disarankan tidak dipergunakan karena perlu revisi besar \\
4. & $01,00 \%-50,00 \%$ & Tidak valid, atau tidak boleh dipergunakan \\
\hline
\end{tabular}

Data yang berupa saran, komentar, dan masukkan dari validator dan guru kelas I SDN Balongjeruk dianalisis menggunakan teknik deskripsi kualitatif. Hasil analisis data tersebut digunakan sebagai dasar untuk merevisi produk.

\section{HASIL}

Pada penelitian \& pengembangan ini dihasilkan produk buku asesmen autentik yang memiliki tingkat kevalidan, keterterapan, dan keterbacaan yang tinggi. Produk yang dikembangkan pada penelitian \& pengembangan ini yaitu buku asesmen autentik. Buku asesmen autentik merupakan pelengkap buku guru dan buku siswa kelas I SD semester 2. Buku asesmen autentik yang dikembangkan berisi asesmen autentik untuk pembelajaran tematik. Buku asesmen autentik ini digunakan sebagai buku panduan guru dalam melakukan asesmen proses belajar siswa.

\section{Deskripsi Produk yang Dikembangkan}

Buku asesmen autentik ini membantu guru dalam memberikan skor, mengolah nilai, serta mendeskripsikan hasil capaian siswa pada tiap aspek dan kompetensi dasar. Buku asesmen autentik ini 
dilengkapi dengan lembar penilaian dan lembar penyimpulan nilai dari masing-masing aspek yang diukur. Penyimpulan nilai dibuat berdasarkan KD dari tiap-tiap mata pelajaran. Dengan demikian, guru dapat dengan mudah menulis nilai maupun mendeskripsikan capaian nilai siswa pada format yang telah disediakan. Buku asesmen autentik yang dikembangkan terdiri atas halaman sampul, kata pengantar, daftar isi, bab I asesmen, bab 2 pemetaan asesmen autentik, bab 3 aspek sikap, bab 4 aspek pengetahuan, bab 5 aspek keterampilan, daftar pustaka dan lampiran.

Halaman sampul berisi bertuliskan judul buku, tema pembelajaran, kelas dan semester, identitas penulis, logo UM, serta identitas program studi serta universitas. Kata pengantar berisi penjelasan mengenai bagian-bagian buku asesmen autentik. Daftar isi berisi daftar judul dan subjudul dari isi buku yang dilengkapi dengan nomor halaman. Bab I asesmen memaparkan tentang konsep dasar asesmen, pengertian asesmen autentik, bentuk asesmen autentik, asesmen autentik pada pembelajaran tematik, dan karakteristik asesmen autentik dalam kurikulum 2013. Bab II Pemetaan Asesmen autentik terdiri dari petunjuk pemetaan asesmen autentik dan pemetaan asesmen autentik. Bab III aspek sikap terdiri dari beberapa sub judul yaitu: petunjuk aspek sikap, rubrik, cara pengolahan nilai, dan penyimpulan nilai.

Bab IV ini terdiri dari beberapa subjudul, yaitu: petunjuk aspek pengetahuan, rubrik, cara pengolahan nilai, dan penyimpulan nilai. Bab V keterampilan ini terdiri dari petunjuk aspek keterampilan, asesmen unjuk kerja, asesmen produk, pengolahan nilai asesmen unjuk kerja dan produk, penyimpulan nilai nilai pada asesmen unjuk kerja dan produk, serta asesmen portofolio. Daftar pustaka merupakan daftar rujukan yang digunakan dalam buku asesmen autentik. Daftar lampiran berisi lembar penilaian, lembar penyimpulan nilai dari asesmen observasi, penugasan, unjuk kerja, produk, dan portofolio, serta format identitas portofolio siswa.

Buku asesmen autentik yang dikembangkan ini mencakup tiga aspek, yaitu aspek sikap, aspek pengetahuan, dan aspek keterampilan. Jadi buku asesmen autentik ini sejalan dengan tuntutan asesmen pada pembelajaran tematik. Hal ini sesuai dengan definisi pembelajaran tematik menurut (Fogarty, 1991) ialah model pembelajaran yang mencampurkan antara beberapa disiplin ilmu yang telah diseting prioritas pembelajaran dari tiap-tiap disiplin ilmu dan memasukkan keterampilan, konsep dan sikap pada proses pembelajaran tersebut.

Asesmen yang dikembangkan pada buku asesmen autentik ini, yaitu asesmen formatif. Asesmen dilakukan ketika proses pembelajaran berlangsung dan secara terus menerus. Hal ini sejalan dengan pernyataan (Marzano, 2006) bahwa asesmen formatif harus dilakukan secepat mungkin ketika proses pembelajaran berlangsung.

Asesmen yang dikembangkan pada buku asesmen autentik yaitu asesmen observasi untuk sikap, asesmen penugasan untuk pengetahuan, dan asesmen unjuk kerja, produk, serta portofolio untuk keterampilan. Teknik asesmen yang digunakan pada buku asesmen autentik ini bervariasi. Hal ini sesuai dengan (Kemendikbud, 2013) yaitu salah satu karakteristik asesmen pada kurikulum 2013 ialah menggunakan teknik asesmen yang bervariasi.

Pengolahan nilai dari masing-masing aspek pada buku asesmen autentik ini dilakukan secara berbedabeda. Capaian dari beberapa nilai sikap yang didapat siswa dianalisis dengan cara mencari modus dari masing-masing sikap yang dikembangkan. Hal ini sesuai dengan yang dikemukakan dalam Lampiran (Kemendikbud, 2014b) bahwa nilai modus adalah nilai terbanyak capaian pembelajaran pada aspek sikap.

Dalam pelaksanaan aspek sikap siswa diminta untuk duduk sesuai dengan urutan nomor absen. Hal ini berguna untuk mempermudah guru dalam melakukan penilaian sikap pada siswa. Pelaksaan asesmen pada aspek sikap akan lebih mudah jika dilakukan dengan tim. Sehingga guru ada yang fokus dengan pembelajaran, dan ada yang fokus hanya mengobservasi sikap siswa selama proses pembelajaran.

Buku asesmen autentik ini menyediakan panduan analisis nilai pengetahuan dengan cara menghitung rata-rata beberapa nilai aspek pengetahuan. Nilai aspek pengetahuan yang diperoleh dirata-rata berdasarkan KD. Perhitungan rata-rata pada nilai aspek sikap tersebut sesuai dengan pernyataan (Kemendikbud, 2014a) yaitu nilai rerata capaian pembelajaran pada aspek pengetahuan.

Pada aspek keterampilan beberapa nilai yang dicapai oleh siswa dianalisis dengan mencari nilai optimumnya. Nilai aspek keterampilan dikelompokkan sesuai dengan KD yang dikembangkan pada aspek keterampilan. Pengolahan nilai pada aspek keterampilan ini sesuai dengan (Kemendikbud, 2014a) yaitu nilai optimum ialah nilai tertinggi capaian pembelajaran pada ranah keterampilan.

Pada asesmen produk yang dinilai yaitu tahapan pengembangan produk. Nilai dari beberapa tahap tersebut kemudian dijumlah dan dianalisis dengan rumus yang telah disediakan. Penilaian yang dilakukan 
ini sesuai dengan tahapan pengembangan produk pada asesmen produk. Seperti halnya tahap pengembangan produk yang dinyatakan oleh (Suharsimi, 2013) yaitu (1) tahap persiapan, (2) tahap pembuatan produk (proses), (3) tahap penilaian produk (appraisal).

Asesmen portofolio yang dikembangkan pada buku asesmen autentik yaitu portofolio pembelajaran siswa. Portofolio pada buku asesmen ini merupakan kumpulan hasil karya siswa yang berupa karya tempel, gambar ekspresi, dan tulisan tegak bersambung yang disimpan pada map. Portofolio yang dikembangkan ini sesuai dengan salah satu jenis portofolio yang dipaparkan oleh (Kemendikbud, 2014a). Pada asesmen portofolio ini dilengkapi dengan format identitas siswa/sampul. Hal ini guna mempermudah siswa dalam menuliskan identitas. Untuk menulis identitas, siswa cukup mengisi format identitas yang telah disediakan.

Untuk mempermudah guru dalam menganalisis nilai siswa, dalam buku asesmen autentik ini dilengkapi dengan lembar penilaian dan lembar penyimpulan nilai. Guru cukup menuliskan nilai yang diperoleh pada format yang telah disediakan.

\section{Hasil Validasi Ahli}

Validasi produk buku asesmen autentik dilakukan oleh tiga validator ahli. Ketiga validator tersebut diantarannya ahli evaluasi, ahli bahasa, dan ahli karakter/sikap. Adapun hasil skor penilaian dari ketiga validator tersebut sebagai berikut, (1) ahli evaluasi mencapai 78\% dengan kriteria cukup valid, (2) ahli bahasa mencapai 90\% dengan kriteria sangat valid, (3) ahli karakter/sikap mencapai 91\% dengan kriteria sangat valid. Dari skor penilaian ahli yang didapat tersebut kemudian dirata-rata, sehingga mencapai 86\% dengan tingkat sangat valid.

Meskipun tingkat kevalidan produk buku asesmen autentik telah sangat valid, namun masih perlu dilakukan revisi. Revisi produk buku asesmen autentik dilakukan berdasarkan pada kritik, saran, dan komentar dari para validator ahli. Hasil diskusi dengan validator juga digunakan sebagai bahan revisi produk asesmen autentik.

\section{Hasil Uji Coba Lapangan}

\section{Keterterapan}

Keterterapan produk buku asesmen autentik dapat diketahui dari analisis data dari angket keterterapan yang diisi oleh subyek uji coba yaitu tiga guru kelas I. Adapun hasil skor penilaian dari ketiga guru tersebut sebagai berikut, (1) guru kelas I A mencapai 96\% dengan kriteria sangat valid, (2) guru kelas I B mencapai 96\% dengan kriteria sangat valid, (3) guru kelas I C mencapai 92\% dengan kriteria sangat valid. Dari skor penilaian guru yang didapat, kemudian dirata-rata sehingga mencapai $95 \%$ dengan kriteria sangat valid.

\section{Keterbacaan}

Keterbacaan produk buku asesmen autentik diketahui dari hasil analis data angket keterbacaan yang didisi oleh tiga guru kelas I. Skor penilaian buku asesmen autenti dari ketiga guru sebagai berikut, (1) guru kelas I A mencapai 83\% dengan kriteria sangat valid, (2) guru kelas I B mencapai 97\% dengan kriteria sangat valid, ( 3) guru kelas I C mencapai 83\% dengan kriteria sangat valid. Dari ketiga skor penilaian tersebut di rata-rata yang kemudian skor keterbacaan buku asesmen autentik mencapai 86\% dengan kriteria sangat valid. Meskipun analisis keterterapan dan keterbacaan buku asesmen autentik menunjukkan sangat valid, namun untuk kesempurnaan buku asesmen autentik masih perlu direvisi. Revisi buku asesmen autentik didasarkan pada saran, kritik, dan komentar dari ketiga guru kelas I yang ditulis pada angket respon guru.

\section{PEMBAHASAN}

\section{Revisi Produk}

Revisi pada buku asesmen autentik dilakukan untuk penyempurnaan produk. Revisi dilakukan berdasarkan hasil saran, kritik, dan komentar dari validator ahli maupun dari subyek uji coba lapangan yaitu guru kelas I SD. Revisi yang dilakukan terhadap buku asesmen autentik untuk lebih jelasnya dapat dilihat pada Tabel 2. 
Tabel 2. Hasil revisi dari Validator dan Subjek Penelitian

\begin{tabular}{|c|c|c|c|}
\hline No. & $\begin{array}{l}\text { Bagian yang } \\
\text { direvisi }\end{array}$ & Saran Revisi & Hasil Revisi \\
\hline A. & Validator & & \\
\hline 1. & Tata tulis & Perlu diperbaiki tentang, tata tulis & $\begin{array}{l}\text { Memperbaiki tata tulis, diantaranya: } \\
\text { Mengganti penulisan angka (misalnya angka } \\
\text { '4') yang menyatakan jumlah dengan kata } \\
\text { (kata 'empat'). } \\
\text { Menambahkan kata 'dan' pada sebelum poin } \\
\text { terakhir dari penjabaran. } \\
\text { Mengganti huruf besar dengan huruf kecil dari } \\
\text { kata pertama pada poin-poin penjabaran. }\end{array}$ \\
\hline 2. & Pemetaan & $\begin{array}{l}\text { Kode rubrik perlu diperjelas, bisa dibuatkan } \\
\text { daftar singkatan/kode. } \\
\text { Istilah sasaran pada tabel pemetaan, cari } \\
\text { istilah yang tepat pada dasarnya itu domain } \\
\text { penilaian. }\end{array}$ & $\begin{array}{l}\text { Membuat daftrar singkatan kode rubrik di } \\
\text { bawah tabel pemetaan. } \\
\text { Mengganti istilah 'sasaran' dengan istilah } \\
\text { 'kemampuan'. }\end{array}$ \\
\hline \multirow[t]{3}{*}{3.} & Aspek Sikap & $\begin{array}{l}\text { Rubrik penilaian perjelas alternatif-alternatif } \\
\text { jawabannya/sikapnya (halaman } 45,46,47,48 \text {, } \\
64, \text { dst). }\end{array}$ & Memperjelas rubrik penilaian \\
\hline & & $\begin{array}{l}\text { Sikap disiplin pada halaman } 54 \text { kurang } \\
\text { relevan, juga pada halaman } 56 \text { semua kaitkan } \\
\text { dengan disiplin waktu. }\end{array}$ & $\begin{array}{l}\text { Mengkaitkan semua indikator penskoran } \\
\text { dengan sikap disiplin waktu. }\end{array}$ \\
\hline & & $\begin{array}{l}\text { Pada halaman } 65 \text { sertakan cara menghitung } \\
\text { modusnya. }\end{array}$ & Menyertakan cara menghitung modus. \\
\hline 4. & $\begin{array}{l}\text { Aspek } \\
\text { Keterampilan }\end{array}$ & $\begin{array}{l}\text { Rubrik khususnya yang berhubungan dengan } \\
\text { keterampilan berbahasa perlu lebih spesifik. } \\
\text { Lihat catatan pada halaman } 93 \text { tentang } \\
\text { deskripsi kompetensi keterampilan sertakan } \\
\text { hasilnya. }\end{array}$ & $\begin{array}{l}\text { Mengubah lebih rubrik keterapilan berbahasa } \\
\text { dengan lebih spesifik. } \\
\text { Menyertakan hasil pada tabel deskripsi } \\
\text { keterampilan. }\end{array}$ \\
\hline & & $\begin{array}{l}\text { Kata ekspresi dan irama perlu dimasukkan } \\
\text { dalam penskoran pada halaman } 96 \text { dan } 98 .\end{array}$ & $\begin{array}{l}\text { Menambahkan aspek penilaian ekspresi dan } \\
\text { irama pada keterampilan menyanyi. }\end{array}$ \\
\hline 5. & Daftar Pustaka & $\begin{array}{l}\text { Baca pedoman penilaian dan pengisian raport } \\
\text { Direktorat Pembinaan SD } 2013 \text {. }\end{array}$ & $\begin{array}{l}\text { Membaca buku yang direkomendasikan, dan } \\
\text { menambahkan karakteristik penilaian pada } \\
\text { kurikulum } 2013 \text { pada bab I. }\end{array}$ \\
\hline 6. & $\begin{array}{l}\text { Lampiran- } \\
\text { lampiran }\end{array}$ & $\begin{array}{l}\text { Halaman } 121,126,150,154 \text {, dan } 159 \text { (PL1, } \\
\text { PL2, dst) berikan keterangan. }\end{array}$ & $\begin{array}{l}\text { Membuat daftar singkatan kode rubrik di } \\
\text { bawah tabel lembar penilaian. }\end{array}$ \\
\hline B. & $\begin{array}{l}\text { Subyek } \\
\text { penelitian }\end{array}$ & & \\
\hline 1. & $\begin{array}{l}\text { Aspek } \\
\text { pengetahuan }\end{array}$ & $\begin{array}{l}\text { Rubrik M3.1b dan P3.2b sebaiknya diperinci } \\
\text { lagi. }\end{array}$ & $\begin{array}{l}\text { Membuat lebih rinci indicator penskoran pada } \\
\text { rubrik M3.1b dan P } 3.2 b\end{array}$ \\
\hline 2. & $\begin{array}{l}\text { Aspek } \\
\text { keterampilan }\end{array}$ & $\begin{array}{l}\text { Petunjuk penggunaan aspek keterampilan } \\
\text { sebaiknya diperjelas lagi. }\end{array}$ & $\begin{array}{l}\text { Memperjelas petunjuk penggunaan aspek } \\
\text { keterampilan. }\end{array}$ \\
\hline
\end{tabular}

\section{SIMIPULAN}

Produk buku asesmen autentik aspek sikap, pengetahuan, dan keterampilan yang dikembangkan telah memenuhi tingkat kelayakan dan dapat digunakan sebagai panduan asesmen di SDN Balongjeruk. Berdasarkan penelitian \& pengembangan yang dilakukan, maka dapat disimpulkan bahwa buku asesmen autentik yang dikembangkan memiliki kelebihan dan kelemahan. Adapun kelebihan hasil penelitian \& pengembangan buku asesmen autentik yaitu. Buku asesmen autentik diawali dengan paparan teori mengenai asesmen. Setiap aspek pada buku asesmen autentik dilengkapi dengan teori pendukung, petunjuk yang jelas, rubrik, cara pengolahan nilai, dan penyimpulan nilai. Dilengkapi cara pengolahan nilai yang sesuai dengan 
(Kemendikbud, 2014a). Setiap aspek yang dinilai dilengkapi dengan lembar penilaian dan lembar penyimpulan nilai, sehingga guru dengan mudah menuliskan nilai siswa. Pada asesmen portofolio dilengkapi dengan format identitas portofolio siswa sehingga siswa dapat menuliskan identitasnya dengan mengisi format yang disediakan. Adapun kelemahan dari produk buku asesmen autentik yang dikembangkan, yaitu. Produk buku asesmen autentik belum diuji cobakan pada skala luas. Analisis nilai siswa membutuhkan waktu yang cukup lama. Dibutuhkan tim pengamat pada asesmen sikap dan unjuk kerja agar pelaksanaan asesmen lebih baik.

\section{DAFTAR RUJUKAN}

Ain, N., \& Kurniawati, M. (2013). Implementasi kurikulum KTSP: Pembelajaran tematik di sekolah dasar. Jurnal Inspirasi Pendidikan, 3(2), 316-328.

Akbar, S. (2013). Instrumen perangkat pembelajaran. Bandung: PT Remaja Rosdakarya.

Arifin, Z. (2013). Evaluasi instruksional: Prinsip-teknik-prosedur Bandung: Remaja rosdakarya. Remaja rosdakarya.

Astuti, D. A., Haryanto, S., \& Prihatni, Y. (2018). Evaluasi implementasi kurikulum 2013. Wiyata Dharma: Jurnal Penelitian Dan Evaluasi Pendidikan, 6(1), 7-14.

Fogarty, R. (1991). Ten ways to integrate curriculum. Educational Leadership, 49(2), 61-65.

Kasmadi, K., Harsiati, T., \& Nurhadi, N. (2016). Pengembangan perangkat asesmen autentik keterampilan menulis kelas VII dalam implementasi kurikulum 2013. Jurnal Pendidikan Humaniora, 4(2), 106-114.

Kemendikbud. (2013). Panduan teknik penilaian di sekolah dasar. Direktorat Pembinaan Sekolah Dasar.

Kemendikbud. (2014a). Lampiran peraturan menteri pendidikan dan kebudayaan nomor 104 tentang hasil belajar oleh pendidik.

Kemendikbud. (2014b). Panduan teknis penilaian dan pengisian rapor di SD. Direktorat Pembinaan Sekolah Dasar.

Kovacek, D., \& Bode, M. L. (1996). Authentic assessment for English language learners: Practical approaches for teachers.

Marhaeni, A. A. I. N. (2015). Asesmen autentik dan pendidikan bermakna: implementasi kurikulum 2013. JPI (Jurnal Pendidikan Indonesia), 4(1), 499-511.

Marzano, R. J. (2006). Classroom assessment \& grading that work. ASCD.

Mueller, J. (2014). Authentic tasks (authentic assessment toolbox).

Suharsimi, A. (2013). Dasar-dasar evaluasi pendidikan edisi 2. Bumi Aksara.

Trianto, T. (2012). Mengambangkan model pembelajaran tematik. Prestasi Pustaka. 